\title{
Role of Career Education Advisor/Expert and Teaching Quality in Student Employability Skills as the Outcome of Higher Education
}

\author{
Gulnaz Zahid \\ Assistant Professor, Center for Counseling and Career Advisory, National University of Sciences and Technology, \\ Islamabad, H-12 Campus. Pakistan \\ gulnazzahid@hotmail.com
}

\section{Doi:10.5901/mjss.2014.v5n27p669}

\begin{abstract}
Quality of education is a multidimensional concept encompassing institutional, teaching and student outcome variables. Effective student transition to labor market as a student outcome owes due importance especially at the higher educational level. This is attainable when quality and strategies in higher education are designed to develop student employability skills and in accordance with the demands of labor market. Therefore, this study investigates the role of career education expert/advisor in improving various aspects of teacher quality with the supposition that student employability skills primarily depend upon the services of education expert but mainly through teaching techniques. Data was collected by the in-depth interviews from the selected teachers of National University of Sciences and Technology and Federal Urdu University, Islamabad. Findings both support and challenge this study's proposed paradigm and offer insight into the multiple roles of education expert/advisor in the universities. Conclusion and suggestions have been made accordingly.
\end{abstract}

Keywords: Career education expert; Teaching Method; Higher education; Student outcomes; Student employability skills

\section{Introduction}

\subsection{Background and rationale}

Definitions of quality education revolve around its five key aspects, i.e., environments, content, processes, outcomes and learners ("UNICEF," 2000). The first four components, depending upon the quality can produce desirable or undesirable affects upon student outcomes. Each of these components has instrumental role for student outcomes and therefore student outcomes form the nexus of the whole debate. This interrelationship of the institutional and teaching variables in connection to student outcomes evolves as a matter of prime significance when we investigate impacts of higher education. Within this framework, linking students of higher education with the labor market emerges as a challenge for which the quality of higher education is evidently responsible.

The foremost function of higher education is the effective student transition from education to work, which is hallmark of the educational success in all the societies. This paper explores these phenomena by re-emphasizing the links between higher education and labor market and by empirically investigating how quality of teachers is connected to linking students with employment and why and how the role of career education advisor/expert enters in this framework. This study contributes in literature by investigating crucial educational factors responsible for linking students with labor market, which can lead to substantial findings for varied cultural contexts.

Quality of higher education is interpreted in varied ways by various stakeholders (Becket \& Brookes, 2008) and teachers' role remains unchallenged in that. Quality of higher education receives global influences and we envision a massive shift of focus from education process and institutional variables to student outcomes. Though it is inevitable to produce student outcomes without considering the input and process variables within the educational system, student outcome can rightly be considered one of the main criteria of quality of education.

All this debate shows that careers form a central point of discussion within the quality framework of higher education. Fact that quality of higher education prepares individuals' ability to fetch employment according to their skills and interests, ability to contribute nationally and ability to find opportunities within the regional and global trends which keeps on increasing their employability to live a self-fulfilling and socially contributive lives, compels us to explore the antecedents and determinants of employability. In this connection, this paper considers entrance into employment as the one of the most substantial, tangible and measurable outcome of higher education. In present era, importance of employment navigates around success of individuals, societies and global development. The self-fulfilling individuals can 
make meaningful, significant and effective contribution at national, regional and global levels. Therefore, careers form a central point of reference for all at both the individual and societal levels.

Importance of careers as the outcome of higher education indicates that its processes, content and environments should emancipate individuals with the potential. This signifies importance of career education expert/advisor in higher education institutes. Therefore, in this corporate world, quality of higher education is intertwined with the opportunities and possibilities of career education. In light of this argument, this study intends to explore the role of education advisor/ expert in uplifting the quality of higher education primarily through improving teaching quality and then reaches at the suggestions relating to the role of education advisor/expert in that. Most importantly, this study aims to test the assumption that education advisor can link students with the labor market through improving teacher quality. Furthermore, if this assumption is supported, it is worthwhile to find the aspects of teaching which carry proponent role for student employability skills and which can be positively influenced by a strategic approach of career education advisor/expert.

Empirical investigation of the roles of career education expert /advisor for various aspects of quality teaching can be of significance to various contexts. Around the world, career advisory has earned firm position in higher education institutes. There is a Center for Counseling and Career Advisory at the National University of Sciences and Technology, Pakistan. Similarly, there is Columbia University Center for Career Education ("Columbia University,"2014), there is a Cawley Career Education Center at the Georgetown University (http://careercenter.georgetown.edu/) and a focus on career education in the Marryville University of St. Louis ("Marryville University," 2013) and similar trends prevail in various other universities. Research-based investigation on the role of career education expert/advisor for linking students to the labor market can be significantly helpful in devising their roles advisor/expert at the university level.

\subsection{Importance of career education in national and international perspective for the quality of higher education}

Career education refers to preparation for the labor market and workforce and facilitating the transition from education to work. Wendy (2005) elaborates change in career education due to a shift of societies from industrial to post-industrial. Watts (2012) refers to this post-industrial society to the "knowledge society", which obviously demands knowledge, cognitive and intellectual skills. Despite of this generic notion, countries at different levels of development have different educational needs (Fasih, 2008), still we cannot deny that labor market trends are likely to influence the college and university level programs ("The Aspen," 2013).Internationally research has identified links between the education and labor markets by research.

Links between quality of teachers and student employability skills have been established previously by the empirical studies (Udofia, Ekpo, \& Nsa, Akpan, 2012; Zinser, 2003) and the role of universities has been found to be crucially important for the development of student employability skills such as by the University of Stirling (http://www.stir.ac.uk/academicpolicy) and hence we can infer the significant importance of higher education for linking students with the labor market.

There is a vast literature regarding connectedness of education with the employability skills of the students but with the mixed results. Research indicating the extent to which higher education institutes (HEI) prepare students for employability need not to mention here rather there is an explicit need to overview the findings reported by various studies on the role of HEl and student employability skills. In this connection, Lowden, Hall, Elliot, and Lewin (2011) have identified that amongst various other reasons, employability skills may be influenced by the extent to which courses meet the needs of labor market. Other studies somewhat provide a glimpse that employability skills go beyond academics and discrepant perceptions between the student and employers exist which can be considered as a consequence of gaps in quality education. Research by Wild and Wood (2013) identified that employers are not much satisfied from certain employability skills of the graduates, which includes business and commercial awareness, self-management and team work, while the graduates and students recognized teamwork, motivation and enthusiasm as important employability skills but lacked confidence in them. All this argument can be summed up in work by Silver (2003), who reported a weak connection between universities and student employability skills.

All this debate indicates that there are numerous reasons for the mismatch between individual's skills and occupations. A mismatch between the student skill and occupation is not only the concern in Pakistani context (Farooq, 2011), it is also a crucial matter of concern in other countries as indicted by the international scholars (Machin \& McNally, 2007). Exploration of factors for this can lead to the evidence-based strategic planning.

Role of career education in student employability has been realized and much debate, review and research has been contributed so far in the literature (Bimrose, Barnes, \& Jamie, 2005; Fung \& Wong, 2012). However, this study is an extension to the previous ones which aims to test the role of career education advisor/expert for student employability 
and through comparing different aspects of quality teaching and related factors. Research from this perspective and from the developing contexts is still scant, therefore it can be said that findings which emerge may be of significance to the contexts closer in problems and challenges to ours.

The paramount importance of teachers for the quality education necessitates their understanding and capacity to develop student employability skills can have potential to improve their teaching style and methods. However, teachers might be lacking perspective with reference to the labor market skills worth focusing for the job entrance and here enters the significant role of career education expert/advisor in the framework. Trends of career education at the university level can shift teaching paradigm from memorization to practicability of information and concepts. This assumption leads to the mediation model in which effective role of education an advisor/expert is mediated through quality teaching for the development of labor market entrance skills of the students.

This study seeks to determine the kind of roles of education expert/advisor which are likely to enhance student employability skills especially through improving particular aspects of teaching and the kind of strategies required to infuse the role of career education advisor/expert in higher education institutes.

\section{Procedure}

Qualitative method was considered to elicit in-depth information relating to the aspects of teaching methods/strategies, which play pivotal role in effectively linking students with labor market and possible roles of career education advisor/expert within this framework. This method provided ample opportunities to investigate context-based issues and teachers' perceptions on the basis of their prior experiences.

For this study, data was collected from 30 faculty members from varied disciplines from the two selected universities. These teachers were approached from selected universities of Islamabad (Pakistan), i.e., the National University of Sciences and Technology (NUST) and the Federal Urdu University. In-depth interviews were conducted with the teachers. A questionnaire was developed in order to conduct the interviews (Table1-3). It comprised of three openended questions and was reviewed by three experts having advance research degree in social sciences and three to five years of work experience at the National University of Social Sciences and Technology.

Face to face interviews were conducted by the researcher. The verbatim statements were recorded by noting down all the responses and themes were developed after analyses. Importance of each of these themes was ascertained by counting the frequency of responses across the sample and calculating the percentages which further assisted in comparing the importance of themes. This method supported addressing the research questions adequately.

\subsection{Sample}

Interviews of 30 teachers were conducted from two selected universities. These two universities were selected on the basis of the Pakistani universities' ranking data ("Top Universities," 2014). One of the top Universities named as National University of Sciences and Technology (NUST, Islamabad) and another university standing on 31 $1^{\text {st }}$ number out of total 64 universities was selected.

Those teachers who were available at the time of data collection from the two selected universities participated in the study entirely on a voluntary basis. From NUST, 6 teachers were from Electrical Engineering Department, 2 were from Physical Geography related department, 1 was from Environmental Science and Engineering, 2 were from the department related to cell Biology and Immunology, 3 were from Business School and 1 was from Civil Engineering. There were 4 female and 11 males in the total sample of 15.

From the Federal Urdu University, 4 teachers were from Human Resource Management, 2 from Urdu department, 1 from Pakistan Studies Department, 3 from Physics Department, 1 from Functional Accounting Department, 1 from Economics Department, 2 from Business studies and 1 from Electrical Engineering Department. There were 7 female and 8 male teachers in this total sample of 15.

This sample was small and purposive but was considered to be adequate for addressing the research questions. The questionnaire developed was at the generic level and therefore findings can be meaningful and applicable for the varied contexts. It is noteworthy that students' socioeconomic background varies considerably between the two universities and hence findings can be generalized to numerous universities having students from various socioeconomic backgrounds. Next given are the results and discussion derived on the basis of in-depth interviews. 


\section{Results and Discussion}

Below given are the results and associated findings which were interpreted by analyzing the responses of the participants on the three main questions of this study. On the basis of findings, a model was developed pertaining to the role of career education advisor/expert for student employability through quality teaching.

Table 1: Responses on the question one

\begin{tabular}{|c|l|c|}
\hline & & Total \\
\hline Question 1 & $\begin{array}{l}\text { Do you think that the subject you are teaching can really develop skills of the students } \\
\text { to seek employment in a company? }\end{array}$ & \\
\hline Theme 1 & Curriculum/courses according to the need and labor market & $26.6 \%$ \\
\hline Theme 2 & Bookish or theoretical knowledge is mostly imparted & $23.3 \%$ \\
\hline Theme 3 & Subject is itself practical & $63.3 \%$ \\
\hline Theme 4 & Teaching styles of the teachers affect students' job seeking and seeking employment & $43.3 \%$ \\
\hline
\end{tabular}

Table 1 shows that less than half of the sample of this study believed in lack of alignment of the courses/ curriculum with the labor market needs. Furthermore, bookish/theoretical teaching was reported as an important reason for lack of student employment skills. On the other hand, above $63.3 \%$ of the sample believed that practicability of the subject is crucial in order to connect teaching with the development of the employability skills of the students.

Majority participants of this sample emphasized teaching styles of the teachers (43.3\%) when compared to the relevancy of curriculum and courses (26.6\%) is the crucial factor for connecting students with the labor market. This shows that teachers play significantly important role when compared to other educational factors such as curriculum and courses. Additionally, practicability of a subject exerts extra advantage for both teachers and students and has better chances for linking the students with the labor market.

Table 2: Responses on the question two

\begin{tabular}{|c|l|c|}
\hline Question 2 & $\begin{array}{l}\text { In what ways your teaching style could improve so that students are } \\
\text { able to seek employment in various companies/industries? }\end{array}$ & \\
\hline Theme 1 & Practical activities/lab /instruments missing & $50 \%$ \\
\hline Theme 2 & Interactive activities/discussions needed & $36.6 \%$ \\
\hline Theme 3 & Teacher training missing or of low quality & $36.6 \%$ \\
\hline Theme 4 & Concept building is required & $3.3 \%$ \\
\hline
\end{tabular}

Table 2 shows that various aspects of teaching methods help students to develop their employability skills. However, the main reason reported for lack of connectedness of teaching style with student employability skills was inadequate focus upon the practical activities, as shared by the $50 \%$ of the participants.

Table 3: Responses on the question three

\begin{tabular}{|c|l|c|}
\hline Question 3 & $\begin{array}{l}\text { Do you think that there is a need of career education /advisor in your } \\
\text { program so that you can link your course to the needs of labor market? }\end{array}$ & \\
\hline Theme 1 & Yes, very important role of education advisor/expert & $43.3 \%$ \\
\hline Theme 2 & Education advisor/expert not needed in the program & $16.6 \%$ \\
\hline Theme 3 & Education advisor/expert can improve/modify program & $20 \%$ \\
\hline Theme 4 & Education advisor can guide students and teachers & $56 \%$ \\
\hline Theme 5 & Education advisor/expert is important for student placement in labor market & $16.6 \%$ \\
\hline
\end{tabular}

Table 3 shows that nearly half of the sample narrated importance of the role of education advisor/expert to link students with the labor market. More than half of the sample shared that education advisor can help both the teachers and students for the development of student employability skills.

Findings of this study support the previous ones which indicate importance of practical side of teaching and learning for student employability. Hefferman, Feng, Angel, and Fang (2010) empirically found eight attributes crucial for the employment of the marketing students when the perspectives of the employers were taken. These eight attributes 
were (a) communication, (b) team work, (c) problem solving, (d) work ethic, (e) desirable persona, (f) customer focus, (g) core skills, and (h) leadership. This signifies the importance of practical work in the curriculum and courses. Similarly, Wheeler (2010) also indicated the embedded nature of practical work in courses and curriculum of the environment management programs with the underlying aim to develop the attributes of graduates for employability. Furthermore, De Weert (2011) indicated that practice-oriented research by universities of applied sciences has an important role in forming the relationship with the professional field. As per these studies it can be deduce that employability skills cannot be developed without having hands-on experience. Hence, the placement of career education expert/advisor in HEI is justified. It also identifies the associated roles. Introducing the practical courses and making teaching learning practical significantly linked to the labor market can be considered foremost important role of an education expert/advisor.

\section{Model on the Role of Career Education Advisor/Expert for Student Employability through Quality Teaching}

This study was conducted to develop a model deeply embedded in the investigation of the role and direction of the career education expert/advisor for the development of student employability skills specifically through teaching methods. Rather than exploration of the domains of job entrance skills such as employability skills, investigation of the aspects of quality teaching deemed necessary for exploration, because they play crucial role in developing student employability skills.

On the basis of results, it can be ascertained that the primary role of career education expert/advisor in the universities can be (a) to review for the practicality and applicability of the courses, and (b) help teachers to improve practical side of teaching and learning other than directly guiding the students.

They can also strategically impart trainings to teachers in order to develop their sensitivity pertinent to the needs of labor market, so that they review courses/curriculum accordingly. Improvement in teaching styles and techniques for the development of student employability skills was also found to be an important concern.

\section{Conclusion and Suggestions}

Career education advisor/expert can play a crucial role to improve the quality of teaching which can strategically link students with the labor market specifically by enriching their practical and applied aspects of both teaching and learning and by reviewing the courses for their practicability. On the basis of findings it can be suggested that universities should place education expert/ advisor in their programs to support both faculty and the students in multiple ways. This research identified primary and secondary roles through a small scale study, which can be a meaningful contribution in both theory and practice.

Further studies can be conducted to investigate strategies/approaches of education advisor/expert in the universities for making courses practical, leading to teacher involvement for improvement in curriculum and instruction for positive student outcomes.

\section{Implications}

This study tests the paradigm leading to the concise findings relating to the primary and secondary roles of a career education expert/advisor for the development and enhancement of student employability skills. Findings are worth application and testing under supervision of the monitoring bodies for effectiveness, beyond a particular context and university.

\section{Limitations}

Major limitation of this study pertains to the sampling technique, i.e., purposive sampling. However, generic nature of questions and cumulative analysis lead to the findings applicable elsewhere most importantly similar to our contexts. Reaching conclusion on the basis of data from the teachers having different expertise can be considered another limitation. Notwithstanding the before, the findings are worth consideration because of involving the faculty members from variety of disciplines. It has provided a general idea with reference to the research questions and findings may be of interest to universities having varied disciplines. 


\section{References}

Becket, N., \& Brookes, M. (2008).Quality management practice in higher education - What quality are we actually enhancing? Journal of Hospitality, Leisure, Sports and Tourism Education, 7 (1), 40-54.doi: 10.3794/johlste.71.174

Bimrose, J., Barnes, S-A., \& Brown, J. (2005).A systematic literature review of research into career-related interventions for higher education. Retrieved from http://www.hecsu.ac.uk/assets/assets/documents/Literature_review.pdf

Columbia University Center for Career Education. (2014). Retrieved from http://www.careereducation.columbia.edu/

De Weert, E. (2011). Perspectives on higher education and labour market: Review of international policy developments. Retrieved from http://www.utwente.nl/mb/cheps/publications/Publications\%202011/C11EW158\%20Final\%20version\%20Themarapport\%20onder wijs\%20-\%20arbeidsmarkt.pdf

Fasih, T. (2008).Linking education policy to labor market outcomes. Retrieved from http://siteresources.worldbank.org/EDUCATION/ Resources/278200-1099079877269/547664-1208379365576/DID_Labor_market_outcomes.pdf

Farooq, S. (2011).Mismatch between education and occupation: A case study of Pakistani graduates. The Pakistan Development Review, 50 (4).

Fung, D., \& Wong, P.S.L. (2012). Using career education and career services to enhance employability: A case of the Hong Kong Polytechnic University. Asian Journal of Counselling, 19(1 \& 2), 75-96. Retrieved from http://hkier.fed.cuhk.edu.hk/journal/wpcontent/uploads/2012/12/ajc_v19n1-2_75-96.pdf

Hefferman, T., Feng, W., Angel, R., \& Fang, Y. (2010).Employability and marketing education: Insights from the United Kingdom. Retrieved from http://www.anzmac.org/conference_archive/2010/pdf/anzmac10Final00140.pdf

Jackson, D. (2013). Student perceptions of the importance of employability skills provision in business undergraduate programs. Journal of Education for Business, 88(5), 271-279. Abstract retrieved from http://www.tandfonline.com/doi/abs/10.1080/0883 2323.2012. 697928\#.U90WdvmSyvM

Lowden, K., Hall, S., Elliot, D., \& Lewin, J. (2011).Employers perceptions of the employability skills of new graduates. London: Edge Foundation. Retrieved from http://www.edge.co.uk/media/63412/employability_skills_as_pdf_-_final_online_version.pdf

Machin, S., \& McNally, S. (2007). Tertiary education system and labour markets. Retrieved from http://www.oecd.org/edu/innovationeducation/38006954.pdf

Marryville University.(2013).The Office of Career and Professional Development. Retrieved From http://www.maryville.edu/studentlife/ services-programs/career-education/

Silver, J.A.K. (2003, September). An evaluation of the employability skills acquired by industrial placement students. Paper presented Education in a Changing Environment. University of Salford. ISBN 0902896660

The Aspen Institute, College of Excellence Program. (2013). A guide for labor market data to improve student success. Retrieved from http://www.aspeninstitute.org/sites/default/files/content/upload/AspenGuideforUsingLaborMarketData.pdf

Top universities of Pakistan, HEC recognized universities, 2013. (2014) Retrieved from http://www.onlinetaleem.com/admissions/ pakistan-universities-hec-ranking.html

Udofia, A. E., Ekpo, A. B., Nsa, S. O., \& Akpan, E. O. (2012). Instructional variables and students' acquisition of employable skills in vocational education in Nigerian technical colleges. Mediterranean Journal of Social Sciences, 3(14), 118-127. doi:10.5901/mjss.2012.v3n14p118

UNICEF. (2000, June).Defining quality in education. Paper presented by UNICEF at the meeting of The International Working Group on Education Florence. Retrieved from http://www.unicef.org/education/files/QualityEducation.PDF

Watts, T. (2012, September).Lifelong career development in an international perspective: Theory, policy and practice. Paper presented in International Networking Conference organized by the ch Foundation for Swiss Co-operation and held in Zurich.

Wendy, P. (2005). A postmodern approach to career education: What does it look like? Perspectives in Education, 23(2), 21-28.

Wheeler, A. (2010). Enhancing employability skills in environmental management students through learning innovation. Retrieved from http://resources.jorum.ac.uk/xmlui/bitstream/handle/10949/15473/Enhancing\%20Employability\%20Skills\%20in\%20Environmental \%20Management\%20Students.pdf?sequence=1

Wild, W., \& Wood, J. (2013).Employability: Transferable skills ranked by students and recruiters. Learning and Teaching in Action, 9 (3), 3-12. Retrieved from http://www.celt.mmu.ac. uk/ltia/Vol9lss3/2_Wild.pdf

Zinser, R. (2003). Developing career and employability skills: A US case study. Education and Training, 45(7), 402-410. 